\title{
ANALISIS PENERAPAN KONSEP INTEGRASI PENGETAHUAN DALAM SISTEM PENDIDIKAN SMP ISLAM TERPADU BUNAYYA
}

\author{
Irwan Saleh Dalimunthe \\ Institut Agama Islam Negeri (IAIN) Padangsidimpuan,Sumatera Utara, Indonesia \\ e-mail: irwansalehdalimunthe2@gmail.com
}

\begin{abstract}
Knowledge integration is critical, for that it is necessary to build an integrated curriculum, namely a curriculum that has a link between revelation and science as well as an Islamic school environment arrangement. This is what SMP IT Bunayya does in educating its students. This study uses a qualitative approach with phenomenological methods. The research subjects were the principal and the school management, who handled the curriculum. Data was collected through interviews, document studies, and observation. Data processing is carried out by unit processing, categorization, and interpretation. The results showed that knowledge integration at SMP IT Bunayya was an integration model with two patterns: First, the model of integration into the curriculum package, namely the integration of aspects of cognitive, affective, psychomotor, etc., spirituality, and social values. Second, the model of integration into the lesson's themes, namely in the design of learning. Meanwhile, the coaching model to achieve the integrated curriculum is carried out with several activities: bina taqwa night, scouts, aqil baligh talk show, yaumiyah practice, and outing class.
\end{abstract}

Keywords: Analysis, Integration, Curriculum

\begin{abstract}
ABSTRAK
Integrasi pengetahuan amat penting, untuk itu perlu membangun kurikulum yang terintegrasi, yaitu kurikulum yang memiliki keterkaitan antara wahyu dengan sains serta penataan lingkungan sekolah yang Islami. Hal inilah yang dilakukan di SMP IT Bunayya dalam mendidik siswanya. Penelitian ini menggunakan pendekatan kualitatif dengan metode fenomenologis. Subjek penelitian adalah kepala sekolah dan pihak menajemen sekolah yang menangani kurikulum. Pengumpulan data dilakukan melalui wawancara, studi dokumen serta observasi. Pengolahan data dilakukan dengan pemrosesan satuan, kategorisasi, dan penafsiran. Hasil penelitian menunjukkan bahwa bentuk integrasi ilmu di SMP IT Bunayya adalah model integrasi dengan dua pola yaitu; Pertama, model pengintegrasian ke dalam paket kurikulum yakni pemaduan pada aspek kognitif, afektif, psikomotorik, spritualitas, dan nilai sosial. Kedua, model pengintegrasian ke dalam tema-tema pelajaran yakni dalam desain pembelajaran. Sedangkan model pembinaan yang dilakukan untuk mencapai kurikulum yang terintegrasi tersebut, dilakukan dengan beberapa kegiatan, yaitu; malam bina takwa, pramuka, talkshow aqil baligh, amalan yaumiyah, dan Outing Class.
\end{abstract}

Kata Kunci: Analisis, Integrasi, Kurikulum

\begin{tabular}{|c|c|c|c|}
\hline FIRST RECEIVED: & REVISED: & ACCEPTED: & PUBLISHED: \\
29 August 2021 & 22 October 2021 & 24 October 2021 & 31 October 2021 \\
\hline
\end{tabular}

\section{PENDAHULUAN}

Integrasi berasal dari kata "integration", yaitu penggabungan atau perpaduan. Perpaduan yang dimaksud adalah hubungan yang bertumpu pada sebuah keyakinan bahwa pada hakikatnya domain telaah, sumber ilmu, dan tujuan ilmu dan agama adalah sama, dia menyatu dan tidak terpisah. Sederhananya integrasi yaitu suatu upaya untuk memadukan ilmu dan agama atau akal dengan wahyu, karena pada hakikatnya keduanya memiliki kesatuan dan keterpaduan (Bagir, 2005). Sementara menurut Sardar integrasi berarti adanya keterkaitan yang padu antara ilmu agama dan ilmu umum. Semua bentuk dan model ilmu pengetahuan tentu saling memiliki keterkaitan dan secara organis ilmu-ilmu itu

Irwan Saleh Dalimunthe 
tidak dapat diabaikan keterkaitannya dengan jiwa, ruh, wahyu yang selalu hidup. Itulah sebabnya Islam tidak hanya memerintahkan penganutnya dan mewajibkan mereka untuk mencari ilmu pengetahuan saja, tetapi Islam dalam ajarannya dijelaskan bahwa ketika mencari ilmu dan ilmu itu sendiri haruslah terhubung dengan ibadah, khilafah, dan istishlah (Zainuddin, 2006). Sedangkan Darda (2015) menyebut integrasi merupakan pertemuan dua titik tower (menara) dua keilmuan, yaitu menara ilmu agama dan menara ilmu-ilmu umum. Adapun pertemuan dua titik keilmuan ini adalah dialog dalam membangun sebuah epistimologis. Jika dialog antar kedua titik keilmuan ini dapat berjalan dengan baik, maka lahirlah konsep keilmuan keislaman yang multidisipliner.

Dalam diskursus keilmuan, istilah integrasi ini sebenarnya memiliki nama yang cukup populer sering diistilahkan dengan kata "Islamisasi". Kata Islamisasi ini sendiri seperti dijelaskan oleh Saefuddin bahwa kata itu berasal dari bahasa Inggris "Islamization". Adapun pengertian dasar dari kata itu adalah pengislaman, yaitu adanya upaya untuk mengislamkan sesuatu. Pada konteks tertentu Islamisasi pengetahuan harus dapat mengaitkan dirinya pada prinsip-pinsip tauhidiyah. Dalam Faishal (2018) dijelaskan bahwa islamisasi pengetahuan adalah upaya yang dilakukan dalam membangun kembali semangat kaum muslimin untuk dapat bangkit dari keterpurukannya. Upaya-upaya untuk keluar dari keterpurukan itu tentu bukan mudah, tetapi kaum muslim harus yakin bahwa dengan mengembangkan ilmu pengetahuan lewat suasana akademik yang baik akan mampu menghasilkan penalaran intelektual yang mapan dan juga dapat menghasilkan kajian-kajian rasional-empirik, berbasis filosofis, tentu dengan tetap menjunjung tinggi ajaran asasi Islam itu sendiri. Jika hal ini dapat dilakukan, maka tidak mustahil kebangkitan peradaban Islam akan terlahir kembali.

Adapun latar belakang munculnya upaya islamisasi ini disebabkan terjadinya fenomena globalisasi terutama dibelahan dunia barat. Globalisasi ini muncul seiring dengan perkembangan cara berpikir manusia. Arus globalisasi telah membawa fakta baru dalam kehidupan yang ditandai dengan banyak temuan-temuan akibat perkembangan ilmu pengetahuan. Disatu sisi perkembangan ilmu pengetahuan membawa manfaat, namun disisi lain telah memberikan efek negatif (Dermadi, 2017). Kemajuan berpikir manusia dan temuan-temuannya saat ini sering mengakibatkan orang menjadi serakah dan merasa power full, serhingga nilai-nilai agama terabaikan.

Mengingat pentingnya persoalan ini, maka para sarjana dan intelektual muslim merasa termotivasi dan mereka berupaya keras dalam merumuskan bagaimana keterkaitan antara ilmu pengatahuan dan agama. Adapun upaya awal yang diusulkan oleh mereka adalah dengan pendekatan konsep islamisasi ilmu pengetahuan. Secara umum islamisasi ilmu sendiri bagi kaum muslim merupakan refleksi dari ketertinggalan kamu muslim dalam berbagai aspek kehidupan dibandingkan dengan dunia modern. Walaupun upaya islamisasi menjadi perdebatan dikalangan para ahli, tetapi langkah ini sangat baik untuk masa depan Islam (Mufid, 2013). Oleh karena itu kaum muslim tidak saja harus mampu dan dapat menguasai ilmu-ilmu keislaman, tetapi umat Islam juga harus membuka diri dan berusaha untuk mampu menguasai ilmu-ilmu modern. Umat Islam sangat membutuhkan adanya integrasi ilmu pengetahuan dengan ilmu-ilmu turats. Hal ini yang disebut oleh AlFaruqi dalam karyanya, Islamization of Knowledge: General Principle and Work Plan, bahwa islamisasi itu tidak hanya mengelaborasi sebatas memberikan teori-teori seputar diskursus di atas, melainkan juga islamisasi itu harus mampu mendesain perencanaan yang lebih praktis (Kurniawan, 2019).

Secara ontologis, integrasi ilmu pengetahuan dalam diskurus kajian Islam pada hakikatnya merupakan sebuah pemahaman dari studi mendalam, sistematis, objektif, dan komprehensif tentang ayat-ayat Allah SWT, baik dalam bentuk kalam-Nya (Al-Qur'an) maupun perbuatan-Nya (alam) (Mufid, 2013). 
Firman Allah SWT dalam Q.S. Al-Hasyar: 22. Artinya: "Dialah Allah, tiada Tuhan selain Dia, mengetahui yang gaib dan yang nyata. Dialah Yang Maha Pemurah lagi Maha Penyayang”.

Dari firman Allah di atas, dipahami bahwa sesungguhnya Allah SWT. memiliki ke-Esaan Zat, ke-Esaan Sifat, dan Ke-Esaan Perbuatan ('Af'al). Atas dasar itu, maka dapat diketahui bahwa Allah SWT. -lah yang menciptakan segenap makhluk yang ada termasuk kesatuan penciptaan alam semesta dan manusia. Itulah sebabnya manusia sebagai ciptaan wajib tunduk dan patuh kepada sistem yang sudah ditentukan Allah SWT. melalui Nabi dan Rasul-Nya. Ketika manusia mengelola alam, maka pada aspek ini juga manusia harus patuh dan tunduk kepada tujuan penciptaan alam itu sendiri. Dalam hal ini manusia harus merujuk kepada sumber hukum yang sudah ditentukan Allah SWT. tentang bagaimana cara memperlakukan alam ciptaanNya. Jadi, intinya manusia bukanlah mahkluk berdiri sendiri dan bebas untuk melakukan apa saja. Hakikatnya manusia itu terikat, mereka tidak dapat lepas dari ketentuan-ketentuan spiritual. Mereka harus menguasai ilmu agama dan ilmu umum yang merupakan sumber berprilaku dan disana ada kesatuan hubungan di antara sifat-sifat Tuhan yang banyak (Dalimunthe, 2002).

Adapun secara epistemologis, integrasi ilmu pengetahuan itu merupakan upaya memadukan antara ilmu-ilmu agama dengan ilmu sains, sebab antara kedua ilmu tersebut diyakini tidak berbeda, keduanya datang dari sumber yang sama. Hanya saja dalam memperolehnya keduanya terlihat berbeda. Ilmu-ilmu agama misalnya, dia diperoleh dan bersumber dari Allah SWT., dengan mengkaji ayat-ayat qauliyah. Sedangkan ilmu sains diperoleh dari hasil observasi dan riset ilmiah terhadap ayat-ayat kauniyah (Kaelany, 1992). Bila dianalisis lebih dalam, kedudukan Islam dalam proses pencarian dan penemuan ilmu pengetahuan sangatlah demokratis dan tetap berhati-hati supaya tidak sampai proses dan pembuktian ilmiah yang dilakukan bertentangan dengan ajaran pokok dalam Islam.
Kemudian secara aksiologis, Islam sangat mengedepankan kemanfaatan bagi kehidupan umat manusia. Kedua model ilmu yang dianggap berbeda satu sama lain, namun dalam Islam keduanya sama pentingnya. Baik ilmu agama maupun ilmu umum, keduanya diyakini dapat mengantar manusia untuk lebih baik dan akan bernilai ibadah jika dikerjakan dengan ikhlas atas dasar nama Tuhan Pencipta. Integrasi ilmu dalam Islam diharapkan mampu untuk meningkatkan ketakutan dan kepatuhan terhadap Allah SWT. Orang yang beragama dan memiliki ilmu pengetahuan idealnya mereka memiliki kepekaan rasa yang tinggi akan hadirnya Tuhan dalam dirinya. Pengetahuan yang mereka miliki tidaklah seberapa dibandingkan luasnya pengetahuan dan ilmu Allah SWT. Pada tataran inilah seharusnya manusia merasa kecil dihadapan Allah SWT. Jika manusia sudah punya rasa seperti itu, maka sulit rasanya mereka melakukan perbuatan-perbuatan yang dapat merugikan dirinya, orang lain, maupun alam dan lingkungannya.

Untuk menggambarkan lebih detail bagaimana keterkaitan agama dan ilmu dengan seseorang, berikut dapat diberi sebuah gambar. Pada bulan November 1989 yang lalu, ilmuwan dengan perangkat teknologinya berhasil mengintip Qausar yang jauhnya 14 miliar tahun cahaya dari bumi tempat manusia tinggal dan mukim. Bagi orang yang membaca berita penemuan ini akan membuat seorang ilmuwan yang beriman mengucap "Allahu Akbar" dengan penuh rasa kagum (Nata, 2005). Selain itu dalam penemuan Friedman dari persamaan Einstein, alam semesta tidaklah statis, melainkan berkembang. Ternyata penemuan (teori) itu telah tertulis dalam Al-Qur'an surah Az-Zariyat ayat 47 (Baiquni, 1983). Dari keterangan tersebut, dapat diambil pemahaman bahwa aspek aksiologi dari kajian integrasi ilmu dapat bernilai praktis, yakni untuk memudahkan urusan hidup umat manusia. Integrasi juga secara aksiologis memberi nilai teologis sehingga dengannya mampu untuk memahami eksistensi dari keagungan Allah SWT. Selain itu, nilai aksiologis dari integrasi berdampak

Irwan Saleh Dalimunthe 
sosiologis, yaitu bisa memposisikan diri manusia untuk hidup dan berkepribadian harmonis, penuh cinta dan kasih sayang karena dapat memaknai sifat-sifat dari Rahman dan Rahim-Nya.

Dari rangkaian penjelasan di atas, maka dapat dipahami bahwa paradigma pendidikan integral perlu dikembalikan sebagai dasar kesadaran ketuhanan, sebab salah satu persoalan besar yang sangat krusial adalah dipisahkannya kegiatan keilmuan dengan agama. Disilah pentingnya sekolah Islam terpadu dan di Indonesia sendiri lembaga semacam ini sudah mulai dikembangkan.

Secara historis Sekolah Islam Terpadu (SIT) merupakan lembaga pendidikan formal yang mulai berkembang pada dekade 1993-an. Munculnya SIT terpadu ini berawal dari lahirnya lima sekolah dasar di wilayah Kota Jakarta dan sekitarnya pada tahun 1993. Kelima sekolah tersebut adalah; 1) SDIT Nurul Fikri Depok, 2) SDIT al-Hikmah Jakarta Selatan, 3) SDIT Iqra Bekasi, 4) SDIT Ummul Qura Bogor, dan 5) SDIT al-Khairat Jakarta Timur. Dengan kemunculan kelima sekolah tersebut, maka terinspirasilah banyak lembaga untuk mendirikan SIT. Sati ini, setelah 14 tahun berlalu, jumlah sekolah yang tergabung dalam oraganisasi Sekolah Islam Terpadu (SIT) sekitar 2.418 lembaga. Sedangkan jumlah tenaga pendidik di SIT yang terdaftar sekitar 80 ribu pendidik (Sasongko, 2017).

Secara umum berdirinya lembaga ini bertujuan untuk meletakkan dasar-dasar dalam menumbuh kembangkan berbagai kecerdasan yang ada pada peserta didik. Di antara kecerdasan itu adalah Intelegence Quotient (IQ), Emosional Quotient (EQ), dan Spiritual Quotient SQ). Dalam perkembangannnya berbagai upaya inovatif dan efektif telah dilakukan untuk mencapai tujuan dalam pengembangan ketiga kecerdasan tersebut. Hal yang paling dasar sebagai ciri khas Sekolah Islam Terpadu (SIT) adalah kurikulumnya. Desain kurikulum lembaga ini diharapkan dapat menjangkau masing-masing bagian dari perkembangan peserta didik, termasuk juga kreativitas yang mencakup integritas dan kondisi tiga ranah, yaitu; ranah kognitif, afektif dan psikomotorik (Frimayanti, 2015).

Keberadaan sekolah Islam terpadu memang sangat penting. Dari penelusuran yang dilakukan maka SIT ini tampaknya sedikit banyaknya sangat dipengaruhi oleh konsep Total Quality Management (TQM). Adapun konsep ini sendiri merupakan upayaupaya yang dapat dilakukan untuk bisa memberikan yang terbaik di dalam sebuah lembaga, tak terkecuali lembaga pendidikan. Secara umum karakteristik TQM adalah 1) Berorientasi kepada pelanggan, baik itu pelanggan internal maupun eksternal; 2) Punya obsesi yang tinggi terhadap peningkatan kualitas; 3) Menggunakan pendekatan saintifik dalam setiap keputusan dan upaya pemecahan masalah; 4) Memiliki komitmen yang berorientasi jangka panjang; 5) Membudayakan kerjasama tim (team work); 6) Berupaya untuk memperbaiki proses secara kesinambungan; 7) Menyelenggarakan pendidikan dengan konsisten dan membuat berbagai pelatihan; 8) Menciptakan suasana kebebasan yang terkendali; 9) Memiliki rasa kesatuan yang terkendali;10) Berupaya untuk menyertakan keterlibatan dari karyawan dan memberdayakannya (Hermanto, 2019).

Sekolah Islam Terpadu dalam prakteknya dapat dimaknai sebagai sekolah yang penyelenggaraan dan tata kelolanya dengan pendekatan mengintegrasikan pola pendidikan umum dengan pola pendidikan agama (kurikulum terpadu), menekankan keterpaduan pada metode pembelajaran untuk mengoptimalkan ranah kognitif, afektif dan konatif atau psikomotorik, memadukan pendidikan aqliyah, ruhiyah dan jasadiyah, dan juga memadukan keterlibatan partisipasi aktif dari lingkungan sekolah, rumah tangga dan masyarakat sekitar.

\section{METODE PENELITIAN}

Adapun pendekatan yang digunakan dalan penelitian ini adalah kualitatif dengan menggunakan metode deskriptif (pemaparan yang tertangkap) yang dipadu dengan fenomenologis (mengungkapkan gejala dan 
keadaan) (Anggito dan Setiawan, 2018), yakni melihat apa yang sedang dilakukan dan tumbuh dalam memberikan pendidikan dan pembinaan terhadap peserta didik sebagai sebuah system Sekolah. Subjek penelitian adalah Kepala Sekolah dan pihak menejemen sekolah yang menangani kurikulum, pembinaan karakter siswa-peserta didik secara langsung, diantaranya Wakil Kepala Sekolah bidang kurikulum dan kesiswaan untuk memahami sejarah sekolah Islam terpadu serta system pendidikan dan model kurikulum, pembina pembina lain yang berkaitan dengan pengembangan kurikulum dan karakter siswa.

Pengumpulan data dilaksanakan melalui wawancara yang mendalam, studi dokumen (statuta sekolah, visi dan misi, buku pedoman pelaksaan program, dan sebagainya), serta observasi. Pengolahan data dilakukan dengan Pemerosesan Satuan, Kategorisasi, dan Penafsiran.

\section{HASIL DAN PEMBAHASAN}

\section{Gambaran Umum SMP IT Bunayya}

Beberapa hal yang perlu dipahami sebagai landasan dan dasar pelaksanaan pada JSIT termasuk SMP Bunayya Padangsidimpuan. Diantaranya adalah:

1. Filosofi Pendidikan Sekolah Islam Terpadu JSIT menjadikan Islam sebagai dasar filosofinya, yakni melandaskan segala sesuatunya kepada ajaran Islam. Dalam konteks lembaga pendidikan, karena lapangan pendidikan adalah bagian wilayah dakwah Islamiyah yang sasarannya adalah manusia dalam lapisan generasi muda yakni anak dan remaja, maka pendidikan yang diselenggarakan merupakan alat dan wadah dalam mencetak generasi muslim yang kaffah, yang memahami tujuan penciptaan, tugastugas kehidupan, yakni generasi yang konsisten hidup dengan mengikuti manhaj alhaya (jalan hidup) hamba Allah yang taat pada ajaran Islam. Secara konsepsional Sekolah Islam Terpadu pada hakekatnya adalah: "sekolah yang mencoba menerapkan konsep pendidikan Islam berdasarkan alquran dan as- sunnah serta dilandasi oleh Undang-Undang Sistem Pendidikan Nasional. Konsep operasional SIT dimaksudkan sebagai penguat (tauqid) dari Islam itu sendiri. Maksudnya adalah Islam yang utuh, menyeluruh, integral, bukan parsial, syumuliah bukan juz'iyah. Hal ini menjadi semangat utama dalam gerak dakwah di bidang pendidikan, ini juga sebagai "perlawanan" tehadap pemahaman sekuler, dikotomi, dan juz'iyah yang berkembang seperti saat ini (Muhab, et al, 2017).

Dengan demikian, atas dasar data yang ditemukan, maka terlihat bahwa Sekolah Islam Terpadu jelas memadukan prinsip ajaran Islam dengan Sistem Pendidikan Nasional. Maka ada komitmen yang kokoh untuk mewujudkan prinsip Islamis dan Nasionalis, dalam bahasa yang lebih memasyarakat adalah mengintegrasikan pendidikan umum dengan pendidikan agama dalam satu jalinan kurikulum. Sehingga seluruh rangkain kurikulum nasional akan dilingkupi dan diwarnai oleh nilai dan prinsip ajaran Islam.

2. Prinsip Dasar Sekolah Islam Terpadu

Ada beberapa prinsip yang dimiliki agar terlaksananya dasar filosofi dan prinsip keterpaduan sebagaimana dipaparkan di atas, yakni: "1). Meyakini bahwa pendidikan Islam merupakan aktivitas dakwah. 2). Pendidikan dilaksanakan dengan tulus ikhlas, dedikasi yang tinggi dan cara yang bijak dan dipandang sebagai kewajiban menjalankan printah Allah SWT; mengajak, menuntun manusia menuju ke jalan Allah (QS. An-Nahl:125) dan pelaksanaannya adalah amanah masyarakat dan dari Allah SWT. 3). Pendidikan pada hakekatnya adalah mengajarkan seluruh kandungan Islam baik dalam Al-quran maupun Sunnah sebagai satu kesatuan 'Ilmu Allah'. Oleh karenanya seluruh kandungan kurikulum di SIT dikembangkan berdasarkan keyakinan dan pandangan yang terpadu dan bersendikan ke tauhidan Allah SWT.

Setakat ini, SIT telah berupaya untuk mengintegrasikan ilmu Allah yang tesurat dalam Alquran dan Sunnah ('Ulumul Qouliyah) dengan nilai kauniyah dan qauliyah dalam bangunan kurikulum. Pendidikan adalah wilyah dakwah yang dilakukan dengan 
menggunakan system manajemen modern sehingga dapat lebih terukur dan terkendali, sehingga dibutuhkan jiwa jiwa tulus ikhlas dan menjadikan tugas dan pekerjaan melaksanakan pendidikan ini dengan selalu berpedoman pada nilai ajaran Islam, sebab tugas dakwah adalah merupakan amanah termulia dari Rasulullah SAW. Sehingga akumulasi dari semua keinginan dakwah dalam bentuk kurikulum yang memadukan antara ayat-ayat Allah yang besifat qauliyah dengan kauniyah, sehingga dalam prinsip Ontologis, Epistemologis dan Aksiologis keilmuannya sudah model integrasi dan interkoneksi dengan menggusur pendekatan dualism, dikotomik dan parsial.

3. Misi Pendidikan Sekolah Islam Terpadu

Misi sekolah ini adalah: "mewujudkan sekolah yang secara efektif mengembangkan potensi fitrah anak didik menuju visi pembentukan generasi yang takwa dan berkarakter pemimpin. Dengan berpijak kepada falsafah yang merujuk kepada pesanpesan pendidikan Islam sebagaimana tercantum dalam Alquran."

Dalam aktualisasinya misi dan tujuan dijabarkan dalam poin-poin operasional yang intinya sebagai target terwujudnya generasi cedas dalam berbagai dimensi, baik keimanan, keilmuan, sikap dan kepemimpinan. Dengan bekal aqidah yang kokoh, ibadah yang baik, akhlak karimah, sungguh-sungguh, memiliki ilmu dan wawasan, dan keterampilan hidup.

4. Strategi Mewujudkan Misi

Dalam mewujudkan sebuah misi banyak hal yang harus diperhatikan, salah satunya adalah strateginya. SMP IT Bunayya sendiri menyadari hal itu, sehingga dirumuskanlah strategi dalam merealisasikan misi yang sudah ditetapkan. Adapun strategi untuk mencapai misi di atas adalah; 1) Mewujudkan lingkungan sekolah yang kondusip. 2) Menerapkan aturan dan norma yang bersendikan nilai-nilai Islam. 3) Menerapkan pembelajaran yang efektif dengan memperkaya dan meluaskan sumber belajar. 4) Mengembangkan pembelajaran yang berpusat pada peserta didik. 5) Melakukan Islamisasi dalam proses pembelajaran. 6) Memperkuat pembinaan kesiswaan dengan kurikulum pendamping. 7) Menjalin kemitraan yang efektif dengan bebagai pihak. 8) Menyelenggarakan sekolah npenuh waktu (fullday school). 9) Memastikan kepala sekolah dan guru memiliki visi, misi, semangat, dan pemikiran (ghirah dan fikroh) serta sikap dan pilaku yang sejalan dengan falsafah, nilai, visi dan missi pendirian SIT. 10) Memberlakukan tata tertib, norma, dan etika yang dibuat berstandar kepada etika dan nilai Islami (akhlak mulia) dan kepatutan sosial. Dan memberikan sangsi tegas bagi siapapun yang melanggarnya.

\section{Standar Pendidikan SMP IT Bunayya}

Secara nasional bahwa pendidikan di Indonesia telah diatur dalam Sistem Pendidikan Nasional dan berbagai regulasi, termasuk adanya rumusan Standar Pendidikan yang mesti menjadi acuan dalam penyelenggaraan pendidikan pada setiap sekolah mulai dari tingkat dasar sampai menengah. Ada delapan standar, yaitu: Pertama, Standar Kompetensi Lulusan. Kedua, Standar Isi. Ketiga, Standar Proses Pendidikan. Keempat, Standar Pendidik dan Tenaga Kependidikan. Kelima, Standar Sarana dan Prasarana. Keenam, Standar Pengelolaan. Ketujuh, Standar Pembiayaan pendidikan terdiri atas. Kedelapan, Standar Penilaian Pendidikan.

Dalam konteks SMP Bunayya, juga memiliki standar baku yang dirumuskan secara nasional dan menjadi pedoman baku pelaksanaan pendidikan pada JSIT. Saat ini JSIT memiliki 12 standar, dan ini telah melampaui standar pendidikan nasional. Adapun rincian dari kedua belas standar tersebut, yaitu:

1. Standar Kompetensi Lulusan Sekolah Islam Terpadu.

Sekolah Islam Terpadu memiliki kekhasan termasuk Standar Kompetensi Lulusan SIT, dengan gambaran umumnya yakni lulusan: 1. Memiliki Aqidah Yang Lurus dengan 5 Kompetensi Dasar, 2. Memiliki Ibadah Yang Benar dengan dua puluh dua Kompetensi Dasar, 3. Berkepribadian Matang dan Berakhlak Mulia dengan enam belas Kompetensi Dasar, 4. Menjadi Pribadi-pribadi

Irwan Saleh Dalimunthe 
yang Bersungguh-sungguh, Memiliki Kedisiplinan, dan Memiliki Kesadaran untuk Mengendalikan Diri dengan Lima Kompetensi Dasar, 5. Memiliki Kemampuan untuk Membaca yang Baik, Menghafal dengan Tuntas, dan Memahami Alquran dengan Secara Baik dengan lima Kompetensi Dasar, 6. Memiliki Wawasan yang Luas (Wawasan Keagamaan dengan lima belas Kompetensi dasar) serta (Wawasan Akademik dengan penguasaan dua puluh empat Bidang Studi), 7 . Memiliki Keterampilan Hidup (life skill), terdiri dari; Pertama, Sehat Bugar dengan tiga belas kompetensi. Kedua, Jiwa Wirausaha, dengan sepuluh kompetensi. Ketiga, Program Pengembangan Diri menyangkut dengan Kepemimpinan dan Karakter Bangsa, Ketampilan Sosial, Kewirausahaan dan Minat Bakat.

2. Standar Isi.

Dalam rumusan standar isi di Sekolah Islam Terpadu, terlihat secara nyata dan jelas bahwa isi pendidikan yang dirumuskan adalah berisi kompetensi yang ingin dimiliki sesuai visi, missi dan tuujuan SIT ini, yang dapat dilihat pada paparan pada kompetensi inti bidang: 1). Spritual, 2). Sikap Sosial, 3). Pengetahuan, 4). Keterampilan, dan Tambahan Khas Keislaman (Alquran dan Sunnah).

Dari kenyataan ini, dapat dilihat bahwa dua hal yang mendasar menjadi program yang bersifat terpadu yakni adanya pemberian pembinaan dan pembekalan terhadap peserta didik sehingga diharapkan dapat menumbuh kembangkan kemampuan spiritual sebagai bekal sekaligus alat kontrol dalam kehidupan, dan secara eksplisit langsung dihubungkan keseluruh capaian kompetensi, mulai dari kesadaran spiritual, sikap sosial, pengetahuan dan keterampilan dengan ayat Alquran dan Hadits/Sunnah Nabi SAW., sehingga menjadi tali pengikat untuk diri peserta didik, dengan harapan munculnya pribadi-pribadi yang memiliki kecerdasan yang terintegrasi (Insan Kamil).

3. Standar Pendidikan Agama Islam.

Pendidikan Agama Islam, menjadi satu standar di SIT dan bukan sebagai sub mata pelajaran, akan tetapi jadi substansi yang mewarnai bagi pelaksanaan pendidikan, dengan tujuan dan fungsi yang cukup mulia. Tujuan Pendidikan Agama Islam adalah: 1). Menumbuhkan iman melalui contoh keteladanan, memupuk dan mengembangkan pengetahuan, penghayatan, pengamalan, pembiasaan, serta memberikan dan memastikan terbentuknya pengalaman peserta didik tentang agama Islam sehingga mereka memungkinkan menjadi manusia yang memiliki kesadaran beragama yang tinggi sesuai dengan perkembangan psikologisnya. 2). Mewujudkan manusia Indonesia yang taat dalam beragama serta benar-benar berakhlak mulia, yaitu, manusia yang syarat dengan pengetahuan, rajin untuk beribadah, cerdas, produktif, jujur, adil, etis, berdisiplin, bertoleransi, menjaga keharmonisan secara personal dan sosial, serta mengembangkan tradisi beragama yang baik dalam milliu sekolah. 3). Menanamkan semangat mencari ilmu (thalabul ilmi) sepanjang hayat dikandung badan.

Disamping ada materi pendidikan agama Islam, juga diberikan "Pembelajaran Al-quran" untuk menumbuhkan cinta dan mengamalkan ajarannya sehingga berdampak pada hati diri peserta didik. Selanjutnya ada juga "Pembelajaran Bahasa Arab", menumbuhkan kesadaran pentingnya bahasa Arab sebagai alat mendalami Al-quran, Sunnah dan Kitab para Ulama.

Dengan pemberian tiga kelompok pengetahuan ini peseta didik diharapkan memiliki dasar untuk mendalami Alquran dan Al-Hadits, Akidah, Akhlak, Fikih dan Sejarah Islam, bagus bacaan Alqurannya, dan bisa hafal, dengan bantuan pengetahuan dan ketrampilan berbahasa arab.

4. Standar Pembinaan Peserta Didik Sekolah Islam Terpadu.

Tujuan pembinaan peserta didik adalah agar mereka terbentuk dengan kepribadian Islami, dan mampu membina diri hingga mereka memiliki dasar-dasar: 1). Kepemimpinan dan Karakter Bangsa, 2). Keterampilan Sosial, 3). Kewirausahaan, 4). Pola Prilaku Hidup Sehat secara Islami, 5). Pola Hidup Gemar Ibadah dan Bangga 
Berislam, 6). Minat dan Bakat, 7). Pengembangan Ketrampilan Penalaran dan Penelitian.

5. Standar Proses Sekolah Islam Terpadu.

Dalam proses pembelajaran SMP Bunayya ini menggunakan pendekatan pembelajaran terpadu dengan teknik, telaah, eksplorasi, rumuskan, presentasikan, aplikasikan, dan keseimbangan pandangan dunia dan akhirat. Maka sangat ketat melakukan; 1. Perencanaan Pembelajaran, khususnya dalam melakukan pemaduan (terpadu) yakni memahami peta kompetensi (inti-dasar), indicator, dan proses internalisasi nilai Islam secara simultan dan berkesinambungan. 2. Menyususn Silabus, sekolah wajib merumuskan silabus dan secara ketat berpijak pada Kompetensi (Inti dan Dasar) serta selalu berpijak pada pembelajaran tematik. Kemduian seluruh rencana akan terakomodir pada rumusan RPP (Rencana Pelaksanaan Pembelajaran) sebagai acuan proses pembelajaran.

6. Standar Penilaian SIT.

Standar Penilaian SIT mengacu pada aketentuan Permendikbud No. 23 Tahun 2016 tentang Standar Penilaian. JSIT hanya melakukan pengembangan dengan kekhasan SIT. Penilaian yang dilakuakan bertujuan untuk; 1). Umum, yaitu; a. menilai pencapaian kompetensi dan karakter peserta didik, $b$. memperbaiki proses pembelajaran, c. sebagai bahan penyusunan laporan kemajuan bekajar. 2). Khusus, yaitu; a. mengetahui kemajuan dan hasil belajar peserta didik, b. mendiagnosis kesulitan, c. memotivasi belajar, memahami diri dan melakukan perbaikan.

7. Standar Pendidik dan Tenaga Kependidikan.

Khusus yang berkenaan dengan standar pendidik dan tenaga pendidik, disamping mengikuti standar yang bersifat nasional, maka secara khas beberapa kriteria dan kompetensi dituntut untuk dimilki, termasuk kepala sekolah dan tenaga kependidikan dan SDM lain yang ikut menjadi subjek terlaksanakannya system pendidikan pada Sekolah Islam Terpadu (JSIT Indonesia, 2017).
8. Standar Sarana dan Prasarana.

Bidang ini terdiri dari; a). Standar Umum yakni standar Sarana dan Prasarana yang tetap mengacu pada permendiknas dan dilengkapi dengan kekhasan SIT. b). Standar Khusus menyangkut; standar lahan, bangunan atau gedung, lingkungan dan ruang terbuka, ruang kelas, masjid dan musalla, toilet, perpustakaan, ruang pimpinan, ruang guru, ruang tata usaha, laboratorium IPA, laboratorium komputer, Unit Kegiatan Sekolah (UKS), ruang OSIS, kantin, serta lainnya.

9. Standar Pengelolaan SIT.

Standar pengelolaan juga mengacu pada Permendiknas nomor; 19 tahun 2007 baru dikembangkan dengan standar SIT mengacu pada kekhasan SIT, meliputi: 1. Perencanaan Program dengan perumusan; Visi, Misi, Tujuan/kebijakan mutu, Rencana Strategis lembaga, Progam kerja Lembaga meliputi jangka pendek (4 tahun) dan jangka panjang (8-10 tahun). 2. Pelaksanaan Program, ini juga mengacu pada Buku Panduan SIT, disamping mengelola berbagai macam potensi seperti: a. pendidik dan tenaga pendidik, b. peserta didik dan orang tua, c. birokrasi pendidik seperti pemerintah daerah, d. masyarakat lingkungan sekolah dan instandi terkakit. 3. Evaluasi, Pengawasan dan Tindak Lanjut.

10. Standar Pembiayaan SIT.

Standar pembiayaan di SIT terdiri dari sebelas standar. Dengan standar inilah kemudian SIT menyusun berbagai program untuk tercapainya standar mutu pendidikan yang baik.

\section{Standar Kerjasama SIT.}

Standar kerja sama SIT mengacu kepada prinsip saling mendatangkan mafaat dan menguatkan satu sama lain. SIT akan selalu terbuka untuk kerja sama dengan berbagai pihak, selama yang dikerjasamakan itu memiliki relevansi dengan kepentingan pendidikan. Bagi SIT kerjasama adalah kekuatan, sebab tanggung jawab pendidikan adalah tanggung jawab bersama, sehingga seluruh komponen bangsa harus memberi kontribusi terbaiknya. 
Melihat dan menganalisa Standar Mutu dan gambaran kurikulum SIT-SMP Bunayya, terdapat beberapa catatan peneliti, yaitu; (1) Kurikulum SIT ini benar-benar memadukan antara kurikulum yang diberlakukan di Kemendikbud dengan yang susun berdasarkan kebutuhan Sekolah Islam Terpadu. Jadi kurikulum SIT ini memiliki ciri khas tersendiri terutama pada bagian muatan keislaman, kurikulum tambahan (ko-kurikuler), serta kurikulum ekstranya (ekstra kurikuler). (2) Dalam Kurikulum Inti, dipadukan ayat-ayat Alquran dan Hadits serta nilai-nilai keislaman lainnya, sehingga seluruh sumber daya yang ada sebagai pelaksana diharuskan untuk memiliki kompetensi dan penguasaan strategi mumpuni untuk memadukan dan memberi warna keislaman dalam seluruh kegiatan pembelajaran. (3) Kurikulum bersifat tambahan atau Ko-Kurikuler, sifatnya pendukung dan sebagai wadah dalam menginternalisasi secara langsung akan nilai yang harus dimiliki peserta didik, bukan saja hanya melulu bersifat materi verbal, akan tetapi banyak sekali lewat pemberian contoh, keteladan, dorongan, pelatihan dan pembiasaan.

\section{Kurikulum Terpadu Dalam Pendidikan Di SMP IT Bunayya}

1. Integrasi Dalam kurikulum pada aspek Kognitif, Afektif, Psikomotorik, Spritualitas dan nilai social.

Menelaah Integrasi Ilmu dalam konsep dan rencana yang dituangkan dalam kurikulum SMP IT ini adalah pemaduan berbagai kegiatan baik menyangkut dengan aspek kognitif, afektif maupun psikomotorik (Amin Abdullah, 2020). Hal ini terlihat secara jelas dan nyata dituangkan dalam bentuk Visi, misi dan tujuan. Secara umum tidak melepaskan adanya keinginan yang kuat dan kokoh untuk mencetak generasi yang memiliki keutuhan keilmuan, sikap dan amaliyah yang tercermin dalam sikap diri pribadi siswa yang memiliki jati diri yang mencerminkan akhlakul karimah.

Aspek Kognitif, ini gunanya adalah mencapai bidang pemahaman atau penguasaan konsep pengetahuan, maka diberikan muatan pengajaran sains dengan agama. Hal ini dapat dilihat pada struktur kurikulumnya dengan penyajian mata pelajaran yang didistribusikan kepada lima pilar utama yakni: 1. Agama dan Akhlak Mulia, 2. Kelompok mata pelajaran kewarganegaraan dan kepribadian, 3. Kelompok mata pelajaan ilmu pengetahuan dan teknologi, 4. Kelompok mata pelajaran estetika, dan 5. Kelompok mata pelajaran jasmani, olah raga dan kesehatan.

2. Model pengintegrasian ke dalam tema-tema pelajaran yakni dalam desain pembelajaran.

Jika ditelaah lebih dalam, maka ditemukan bahwa model integrasi kurikulum di SIT-SMP Bunayya juga benar-benar mengacu kepada teori Amin Abdullah (2020). Adapun model kedua ini sebagai berikut:

a. Aspek Konsepsional

Pada level isi pendidikan yang dirumuskan berisi kompetensi yang ingin dimiliki yang dapat dilihat dengan teraplikasi pada kompetensi: Spritual, Sikap Sosial, Pengetahuan, Keterampilan, dan Khas Keislaman (Alquran dan Sunnah).

b. Aspek Paraktikal

Bicara aspek praktikal ini adalah kenyataan yang dilakukan sebagai tindakan nyata untuk mencetak generasi harapan. Dapat diklasifikasi kedalam dua hal yaitu:

\section{Kesiapan Guru}

Pembinaan Guru. Guru di lembaga ini semua direkrut dengan sangat selektif. Menjadi pertimbangan adalah mereka yang memiliki kompetensi yaitu: kompetensi keilmuan, kepribadian (pemahaman dasar ajaran Islam termasuk yang terkait dengan bidang ilmu yang ia dalami dan akan ajarkan, penghayatan dan akhlakul karimah), dan skill mengajar. Setelah mereka dinyatakan lulus oleh Panitia Seleksi dengan proses kerjasama pihak sekolah dengan JSIT maka mereka di upgrade berdasarkan ketentuan-ketentuan yang berlaku.

Pelatihan, dalam pelatihan ini para calon guru diberikan muatan pemahaman tentang filosofi dan paradigm JSIT. Dan dalam kaitan ini oleh lembaga wilayah JSIT dipastikan terlibat betul dalam kegiatan pelatihan, sebab lembaga JSIT adalah bagian yang bertanggungjawab dalam mengawal dan 99 
mewujudkan mutu sekolah. Sebab seperti diungkapkan di awal JSIT menghasilkan dan menetapkan Standar pendidikan diseluruh jenjang yang terhimpun atau ikut dalam jaringan.

Pembinaan Kepribadian, salah satu hal pokok menjadi sarat diterima menjadi guru disini adalah adanya komitmen dan ikrar untuk bersedia mendapat pembinaan yang sudah mejadi kewajiban pada sistem di JSIT yaitu: ikut pengajian untuk memperdalam ajaran agama Islam secara rutin dalam satu kali kegiatan tiap minggu, malam bina iman dan takwa, kegiatan seminar yang rutin minimal satu kali dalam satu semester (Wawancara Fatwahairani, 2020).

\section{Proses Pembelajaran}

Disamping sistem penerimaan guru di lembaga ini dengan mengikuti standar dan adanya pelatihan, maka pemahaman tentang kurikulum serta pembuatan dan penyususnan Rencana Progam Pembelajaran (RPP). Ada dua model RPP di lembaga ini yaitu: RPP sekala Nasional dengan mengikuti regulasi nasional dan ada RPP lembaga pendidikan sesuai ketentuan JSIT. Lebih jelasnya diuraikan dibawah ini gambaran RPP mata pelajaran Biologi:

a) Kompetensi Dasar Serumpun:

Pertama, melaksanakan pengamatan objek secara terencana dan sistematis untuk memperoleh informasi gejala alam biotik dan abiotik. Kedua, mengidentifikasi ciri-ciri makhluk hidup.

b) Indikator:

Pertama, Bidang Spritual, terdiri dari; mensyukuri nikmat yang telah Allah berikan, mengetahui ciptaan Allah dan pentingnya ilmu bagi kehidupan kita.

Kedua, Bidang Pengetahuan, terdiri dari; menjelaskan pengertian komponen biotik, menyebutkan beberapa contoh dari komponen biotik. menjelaskan pengertian komponen abiotik, menyebutkan beberapa contoh dari komponen abiotik, menjelaskan gejala alam biotik yang biasa ditemui dalam kehidupansehari-hari, menjelaskan gejala alam abiotik yang biasa ditemui dalam kehidupan sehari-hari.
Mencermati KD yang ingin ditanamkan terlihat model integrasi ditingkat ini yakni memadukan dimensi capaian kesadaran Spritual dengan Kognitif.Ini artinya adalah bahwa setiap proses pembelajaan mesti ada gerakan integrasi sehingga mental dan pengetahuan peserta didik terbentuk secara terpadu. Gambaran selanjutnya adalah bahwa saat proses pembelajaran dilaksanakan tentu guru mempedomani rancangan yang sudah dirumuskan dalam RPP, maka guru tidak melewatkan untuk mengintegrasikan dengan ajaran Islam melalui pembahasan materi dengan pendekatan integrasi. Sehingga di dalam RPP setiap materi disiapkan nilai-nilai yang akan dilaksanakan dalam pembelajaran sebagai Nilai Islam yang dipadukan dengan penyebutan bidang ukhrawi sebagai terminologisnya. Seperti uraian berikut.

a. Mempelajari prinsip dari; berhati-hati dalam segala hal, Perencanaan yang matang, Pemeliharaan yang baik.

b. Mempelajari prinsip Ihsan dalam Islam seperti Hadits Arbain ke-2 tentang Islam, Iman dan Ihsan: Umar R.A berkata," ketika kami tengah berada di majelis bersama Rasululloh SAW pada suatu hari, tiba-tiba tampaklah di hadapan kami seorang lakilaki yang berpakaian putih, berambut sangat hitam, orang itu berkata lagi. "Beritahukan kepadaku tentang ihsan." Nabi saw menjawab, "engkau beribadah kepada Allah SWT., seakan-akan engkau melihat-Nya, walaupun engkau tidak melihatnya".

c. Mempelajari tafsir Al Quran surat Al Mulk ayat 3 sampai 4: "yang menciptakan tujuhlangit berlapis-lapis. Tidak akan kamu lihat sesuatu yang tidak seimbang pada ciptaan Tuhan Yang Maha Pengasih. Maka lihatlah sekali lagi (dan) sekali lagi, niscaya pandanganmu akan kembali kepadamu tanpa menemukan cacat dan ia (pandanganmu) dalam keadaan letih".

3. Sekenario Pembelajaran.

Dalam proses pembelajaran maka seorang guru harus merencanakan scenario pembelajaran. Seperti dalam mata pelajaran Biologi ini, guru sudah siapkan skenario seperti ini: 
Guru menyampaikan dalil terkait materi, Firman Allah dalam al-Qu'ran, yaitu:

Tumbuhan: "Dan Kami turunkan air yang banyak tercurah. Supaya Kami tumbuhkan dengan air itu biji-bijian dan tumbuhtumbuhan, dan kebun-kebun yang lebat". (QS an-Naba': 14-16).

Air: Surat al-Jatsiyah ayat 5, yang artinya: "Dan pada pergantian malam dan siang dan hujan yang diturunkan Allah dari langit lalu dihidupkannya dengan air hujan itu bumi sesudah matinya; dan pada perkisaran angin terdapat pula tanda-tanda (kekuasaan Allah) bagi kaum yang berakal." (QS. al-Jatsiyah: 5). Tanah: Surat al-Hijr ayat 19 yang artinya: "Dan kami telah mengham-parkan bumi dan mEnjadikan padanya gunung $\neg$ gunung dan Kami tumbuhkan padanya segala sesuatu menurut ukuran." (QS. Al-Hijr: 19).

Angin: Allah, Dialah yang mengirim angin, lalu angin itu menggerakan awan dan Allah membentangkannya di langit menurut yang dikehendakinya, dan menjadikannya bergumpal-gumpal; lalu kamu lihat hujan keluar dari celah-celahnya, maka apabila hujan itu turun mengenai hamba-hambaNya yang dilcehendakiNya tiba-tiba mereka menjadi gembira. ( QS. Ar-Rum: 48).

4. Model Pembinaan sesuai kurikulum dalam usaha terwujudnya Integrasi pengetahuan kedalam sikap kepribadian.

Model Pembinaan sesuai kurikulum dalam usaha terwujudnya Integrasi pengetahuan kedalam sikap kepribadian yang dilakukan SMP IT Bunayya adalah sebagai berikut:

Pertama, Malam Bina Takwa. Malam Bina Takwa (MABIT), Ifthar Jama'i atau pelaksanaan Puasa Sunat Bersama lalu dilakukan Buka Puasa Bersama dengan disertai beberapa even pemberian pembinaan baik menyangkut dengan ukhuwah Islamiyah, maupun melakukan ajaranan agama yang lain sebelum acara bukaan dan sesudah Salat Maghrib.

Kedua, pramuka. Pramuka yang dilakukan disekolah dalam bentuk kegiatan hari hari tertentu dan juga dilakukan berkemah. Kegiatan Pramuka ini dilakukan dengan tujuan mencapai jiwa kepemimpinn juga sebagai wadah untuk mempraktekkan ajaran Islam, seperti adanya Tausiah, Salat Berjamaah dan praktek keagamaan lain khususnya hidup sebagai seorang muslim yang taat. Mereka ini dipandu oleh guru dan Pembina pramuka yang terseleksi sehingga anak anak atau siswa yang ikut kegiatan mesti sama kondisinya sebagaimana dalam bimbingan orang tua mereka dilingkungan rumah tangga.

Talkshow Aqil Baligh

Ketiga, Talkshow Aqil Baligh,. Kegiatan ini adalah usaha membiasakan diri siswa untuk membiasakan diri dalam memanfaatkan forum diskusi sebagai sarana belajardanmelatih diri mengelola kegiatan yang melibatkan orang banyak. Disebut sebagai talkshow akil baligh adalah karena bahan kajiannya disesuaikan dengan kebutuhan sesuai tingkatan usia mereka yang baru usia akil balihg. Bukan saja mempertimbangkan materi akan termasuk mempertimbangkan yang menjadi Narasumber. Dari kegiatan ini diharapkan dapat mempercepat capaian tujuan dari didirikannya SMP ini.

Keempat, Amalan Yaumiyah. Di lembaga ini ada yang khas dan efektif membentuk kepribadian para siswa yakni bentuk pembinaan dengan amalan sehari-hari yaitu: a. Salat Sunat, waktu pelaksanaan salat sunat ini adalah Salat Dhuha minimal 4 rakaat setiap hari, Salat Tahajjut minimal 2 rakaat dan 1 rakaat witirnya dan Salat Tahiyatul Masjid. b. Soum Sunnah, puasa hari senen dan kamis minimal $1 \mathrm{x}$ dalam 1 minggu, dan hari hari istimewa seperti Ayyamulbidh, 'Arafah dan sebagainya, c. Thilawah dengan setengah juz setiap hari, d. Tahfiz 5 ayat setiap hari.

Outing Class (Pembelajaran di Luar Kelas)

Kelima, Outing Class. Salah satu kegiatan yang dianggap dapat mengintegrasikan berbagai dimensi kompetensi anak sesuai missi SMP IT Bunayya ini termasuk dalam menyentuh capaian IDCP ini adalah Outing Classse kaligus mereka merasakan Merdeka Belajar. Outing Class demikian penjelasan dari Khoiruddin Rambe (Ketua Yayasan) mengajak

Irwan Saleh Dalimunthe Analisis Penerapan Konsep Integrasi Pengetahuan Dalam Sistem Pendidikan Smp Islam Terpadu Bunayya 
peserta didik belajar di luar kelas. Pembelajaran bisa berlangsung di halaman sekolah, taman, berjalan-jalan di pasar tradisional dan modern, berkunjung ke dunia usaha dan industri juga belajar di alam terbuka. Rabu, 19 Februari 2020 SIT Bunayya Padangsidimpuan (SD \& SMP) menggelar pembelajaran di alam terbuka, sebanyak 690 siswa berkelompok sesuai kelasnya memilih tempat yang nyaman untuk belajar di alam Syaakirah the view \& resto, Aek Sabaon (sebuah objek wisata di Tapanuli Selatan). Dengan mengusung tema "Alam Takambang Jadi Guru" alam yang membentang luas ini dengan segala isinya, begitu banyak pelajaran yang bisa diambil darinya. Masing-masing kelas belajar sesuai materi dantema belajar pada hari itu dengan memanfaatkan alam terbuka.

Selama proses pembelajaran outing class, guru dan peserta didik dapat membangung hubungan yang lebih dekat, lebih santai (fresh), dan tentunya dengan pembelajaran model outing ini pembelajaran dapat lebih menyenangkan. Selain itu pembelajaran outing mampu juga mengurangi kejenuhan dalam proses belajar mengajar sehingga peserta didik lebih mudah untuk menerima informasi pembelajaran, menambah kecintaan dan kepedulian mereka terhadap alam dan lingkungan sekitar, mengajak mereka bersahabat dengan alam dan arif memberlakukan alam sekitar beserta sosio kulturalnya, meningkatkan kemampuan dalam bercerita dan merangsang kreativitas. Asiknya lagi bahwa beberapa Oruangtua juga ikut mendampingi kegiatan Outing Class SIT Bunayya Padangsidimpuan. Tentu akan menambah semarak dan pada saatnya mereka akan memberi catatan masukan. Di sela-sela acara dilakukan survei kecil-kecilan secara acak diantara siswa (begitu penuturan beliau), bagaimana perasaan mereka dengan kegiatan Outing Class ini, danapakah melelahkan. Semua mengatakan senang, gak terasa lelah, kalau bisa sering-sering seperti ini dan kalau nanti ada Outing Class agar lebih lama lagi pulangnya. Selesai sholat Zuhur berjama'aah di Playground dan kultum, siswa diberi kesempatan untuk mengeksplorasi kawasan wisata alam favorit di Tabagsel saat ini. Alhamdulillah sekitar pukul 15.00 wib semua bersiap-siap pulang, sekaligus "operasi semut" membersihkan lokasi yang dipakai.

\section{SIMPULAN}

Ada beberapa kesimpulan yang dapat diambil dari penelitian ini adalah: Pertama, Sekolah Menengah Pertama (SMP) Islam Terpadu ini mengikuti Sistem Pendidikan yang merujuk atau mengikuti ketetapan Pimpinan Pusat Jaringan Sekolah Islam Terpadu (JSIT) dan selalu mendapat pembinaan dan evaluasi dari Pimpinan Pusat atau Pengurus/Bidang yang berkompoten untuk pengendalian mutu. Kedua, Bentuk Integrasi Ilmu pada SMP IT Bunayya adalah Model Integrasi dengan dua pola, yaitu dengan merujuk kepada teori $\mathrm{M}$. Amin Abdullah. Dua pola model integrasi ilmu yang diterapkan oleh SMP IT Bunayya meliputi; Pertama, model pengintegrasian ke dalam paket kurikulum yakni pemaduan pada aspek Kognitif, Afektif, Psikomotorik, Spritualitas dan nilai sosial, termasuk nilainilai keislaman dan sains. Kedua, model pengintegrasian ke dalam tema-tema pelajaran yakni dalam desain pembelajaran.

Kemudian untuk model pembinaan disesuaikan dengan kurikulum dalam usaha terwujudnya Integrasi pengetahuan kedalam sikap kepribadian. Hal ini dilakukan dengan beberapa kegiatan, yaitu; 1). Malam Bina Takwa (MABIT), Ifthar Jama'i atau pelaksanaan Puasa Sunat Bersama lalu dilakukan Buka Puasa Bersama dengan disertai beberapa even pemberian pembinaan baik menyangkut dengan ukhuwah Islamiyah. 2). Pramuka, yaitu dilakukan disekolah dalam bentuk kegiatan hari hari tertentu dan juga dilakukan berkemah. 3). Talkshow Aqil Baligh, kegiatan ini adalah usaha membiasakan diri dalam memanfaatkanforum diskusi sebagai sarana belajar dan melatih diri mengelola kegiatan yang melibatkan orang banyak. 4). Amalan Yaumiyah, yaitu: a. Salat Sunat, b. Shaum Sunnah, c. Thilawah dengan setengah juz setiap hari, d. Tahfiz 5 ayat setiap 
hari. 5). Outing Class sekaligus Merdeka Belajar. Outing Class adalah mengajak peserta didik belajar di luar kelas. Pembelajaran bisa berlangsung di halaman sekolah, taman, berjalan-jalan di pasar tradisional dan modern, berkunjung ke dunia usaha dan industri juga belajar di alam terbuka seperti objek-objek wisata daerah.

\section{DAFTAR PUSTAKA}

A., Baiquni. (1983). Islam dan Ilmu Pengetahuan. Jakarta: Pustaka, 1983.

Abidin, B. Z., et al., (2005). Integrasi Ilmu dan Agama Interpretasi dan Aksi, Bandung: Mizan.

Amin, A. M. (2020). Multidisiplin, Interdisiplin, Transdisiplin, Metode Studi Agama dan Studi Islam di Era Kontemporer, Yogyakarta, IB Pustaka Litera Cahaya Bangsa.

Anggito, M., dan Setiawan, S. (2018). Metodologi Penelitian Kualitatif. Bandung: CV. Jejak.

Bagir, H. dan Abdalla, U. A. (2020). Saintis Religius, Agama Saintifik, Dua Jalan Mencari Kebenaran, Bandung, Mizan.

Baqir, H. (2019). Memulihkan Sekolah Memulihkan Manusia, Meluruskan Kembali Falsafah Pendidikan Kita, Bndung, Mizan.

Dalimunthe. I. M. (2002). Implementasi Tauhid Ilmu (Suatu telaah Dengan Pendekatan Asumsi Filosofis). FITRAH: Jurnal Kajian Ilmu-ilmu Keislaman, 10(1), 191.

Darda, A. (2016). Integrasi ilmu dan agama: Perkembangan konseptual di Indonesia. At-Ta'dib: Journal of Pesantren Education, 10(1). 33-46.

Dermadi. (2017). Integrasi Agama Dan Ilmu Pengetahuan. Depok: Diandra Kreatif.

Faishal. (2019). Integrasi Ilmu dalam Pendidikan. Ta'dibi: Jurnal Manajemen Pendidikan Islam, 6(1), 104-123.

Frimayanti, A. I. (2015). Latar Belakang Sosial Berdirinya Lembaga Pendidikan Islam Terpadu di Indonesia. Al-Tadzkiyyah: Jurnal Pendidikan Islam, 6(1), 27-45.
H. D, Kaelany. (1992). Islam dan Aspek-Aspek Kemasyarakatan. Jakarta: Bumi Aksara.

Kurniawan, S. (2019). Perspektif Umat Islam Tentang Agama Dan Ilmu Pengetahuan: Dari Dikotomi ke Integrasi. Dinamika Penelitian: Media Komunikasi Penelitian Sosial Keagamaan, 19(1), 145-166.

Mufid, F. (2013). Integrasi Ilmu-Ilmu Islam. Equilibrium, 1(1), 55-71.

Mufid, F. (2013). Integrasi Ilmu-Ilmu Islam. Jurnal Equilibrium, 1(1), 55-71.

Muhab, S. (2010). Standar Mutu Sekolah Islam Terpadu Jaringan Sekolah Islam Terpadu. Jakarta: JSIT Indonesia.

Nasution, M. H. (2019). Manajemen Mutu Terpadu (MMT) Dalam Pendidikan Islam. Al-Muaddib: Jurnal Ilmu-Ilmu Sosial Dan Keislaman, 4(2), 228-248.

Nata, N. et al., (2005). Integrasi Ilmu Agama dan IlmuUmum. Jakarta: Rajawali Press

Saefuddin, AM, (2010). Islamisasi Sains dan Kampus. Jakarta: PT. PPA Consultansts.

Sasongko, Agung. 2017. Dalam https://www.republika.co.id/berita/duni aislam/islamnusantara/17/07/15/ot3za23 13-pesat-perkembangan-sekolah-islamterpadu/.

Zainuddin, M. (2006). Filsafat Ilmu Perspektif Pemikiran Islam. Jakarta: Lintas Pustaka. 